\title{
PELATIHAN MANAJEMEN PADA KOPERASI MAKMUR SEJAHTERA KELURAHAN TITIWUNGEN SELATAN KECAMATAN SARIO KOTA MANADO
}

\author{
Sam J. R. Saroinsong \\ Prodi Ilmu Hukum, Fakultas Ilmu Sosial, UNIMA \\ samsaroinsong@yahoo.com
}

\begin{abstract}
Today the government is aggressively implementing and meningkatkanpembangunan, both material and spiritual development. One area that is being promoted is the business world in order to reduce the number of unemployment in Indonesia is increasing every year. In the business world as well as in the field of cooperative development with all its activities, whether business, skills and awareness activities as well as awareness of cooperatives. All formal and informal organization requires management functions. Because without good management, the organization's goals will not be achieved in an efficient training of cooperative management is essential in the construction and development of cooperatives, including cooperatives prosperous located in the Village Titiwungen Southern District Sario Manado because the success or failure of cooperation depends on the level of knowledge and skills of managers and members of the cooperative, Therefore, training is needed to provide adequate supplies to the board and members, in order to play an active and dynamic for the progress of the cooperative. This devotion activity aims to provide the knowledge of the management of cooperatives to cooperatives to run well and a sustainable for the common welfare. The method used in this devotion is the lesson in class methods (lectures, conferences, case studies, games, program instructions,brainstroming). The results obtained in this training, namely management and members of the Village Cooperative Makmur Sejahtera South Titiwungen District of Sario Manado City has knowledge of cooperative management.
\end{abstract}

Keywords: Training, cooperative management.

\section{PENDAHULUAN}

Koperasi adalah organisasi bisnis yang dimiliki dan dioperasikan oleh orangseorang demi kepentingan bersama. Koperasi melandaskan kegiatan pada prinsip gerakan ekonomi rakyat yang berdasarkan asas kekeluargaan. Pada masa sekarang secara umum koperasi mengalami perkembangan usaha dan kelembagaan yang mengairahkan. Namun demikian, koperasi masih memiliki berbagai kendala untuk pengembangannya sebagai badan usaha. Hal ini perlu memperoleh perhatian dalam pembangunan usaha koperasi pada masa mendatang. Peran koperasi dalam perekonomian Indonesia paling tidak dapat dilihat dari Kedudukannya sebagai pemain utama dalam kegiatan ekonomi di berbagai sektor Penyedia lapangan kerja yang terbesar serta Pemain penting dalam pengembangan kegiatan ekonomi lokal dan pemberdayaan masyarakat .

Pemberdayaan koperasi secara tersktuktur dan berkelanjutan diharapkan akan mampu menyelaraskan struktur perekonomian nasional, mempercepat pertumbuhan ekonomi nasional, mengurangi tingkat pengangguran terbuka, menurunkan tingkat kemiskinan, mendinamisasi sektor riil, dan memperbaiki pemerataan pendapatan masyarakat. Pemberdayaan koperasi juga akan meningkatkan 
pencapaian sasaran di bidang pendidikan, kesehatan, dan indikator kesejahteraan masyarakat Indonesia lainnya.

Sulit mewujudkan keamanan yang sejati, jika masyarakat hidup dalam kemiskinan dan tingkat pengangguran yang tinggi. Sulit mewujudkan demokrasi yang sejati, jika terjadi ketimpangan ekonomi di masyarakat, serta sulit mewujudkan keadilan hukum jika ketimpangan penguasaan sumberdaya produktif masih sangat nyata. Dengan demikian dapat dikatakan bahwa koperasi sangat berperan dalam membangun dan mengembangkan potensi dan kemampuan ekonomi anggota pada khususnya dan masyarakat pada umumnya serta untuk meningkatkan kesejahteraan ekonomi dan sosialnya.

Untuk mencapai tujuan Koperasi, perlu diperhatikan adanya sistem Manajemen yang baik, agar tujuannya berhasil, yaitu dengan diterapkannya fungsi-fungsi Manajemen. Adapun Fungsifungsi Manajemen menurut G Terry adalah :

a. Planning (Perencanaan)

b. Organizing (Pengorganisasian)

c. Actuating (Penggerakan untuk bekerja)

d. Controlling

(Pengawasan/

Pengendalian)

Ilmu Manajemen adalah suatu ilmu yang mempelajari bagaimana cara mencapai tujuan dengan efektif dan efisien dengan menggunakan bantuan / melalui orang lain, Yang dimaksud orang lain disini mempunyai arti yang sangat luas, karena dapat berupa bantuan dalam ujud pikiran, tenaga dan dapat pula intuisinya.

Masyarakat pesisir muara Sario Kelurahan Titiwungen Selatan Kecamatan Sario Kota Manado dengan karateristik perekonomiannya yang heterogen mengharapkan adanya suatu organisasi perekonomian yang dapat membantu meningkatkan perekonomian anggota yang bermuara pada tercapainya kesejahteraan masyarakat sehingga pada tahun 1999 mereka mendirikan Koperasi dengan Nama Koperasi Makmur Sejahtera.

Koperasi Makmur Sejahtera ini kemudian dalam perkembangannya mengalami kemunduran sampai akhirnya tidak aktif lagi. Hal ini disebabkan karena berbagai faktor diantaranya yaitu kurangnya pengetahuan masyarakat tentang Badan hukum koperasi yang mereka dirikan tersebut, Tingkat partisipasi anggota koperasi masih rendah, ini disebabkan sosialisasi yang belum optimal, serta Manajemen koperasi yang belum professional.

Untuk mengaktifkan kembali koperasi memerlukan kerjasama dan peran serta dari berbagai pihak termasuk didalamnya Perguruan Tinggi dimana Perguruan Tinggi dengan salah satu tugas pokoknya Pengabdian Pada Masyarakat diharapkan mampu menjadi motivator dan penggerak aktivitas masyarakat agar kembali berperan terutama dalam kegiatan koperasi untuk meningkatkan kesejahteraan masyarakat serta mengubah Imej koperasi 
sebagai ekonomi kelas dua yang masih tertanam dalam benak masyarakat yang menjadi sedikit penghambat dalam pengembangan koperasi menjadi unit ekonomi yang lebih besar, maju dan punya daya saing dengan perusahaan-perusahaan besar.

Masyarakat Pesisir Muara Sario Kelurahan Titiwungen Selatan Kecamatan Sario Kota Manado sangat mengharapkan agar koperasi ini kembali aktif sehingga melalui Kegiatan Pengabdian kepada masyarakat yang didanai oleh proyek DIPA 2012 dengan pelaksana Dosen Program Studi Hukum yaitu Sam Saroinsong SH, telah mengaktifkan kembali koperasi Makmur Sejahtera ini melalui prosedur hukum yang berlaku.

Dengan diaktifkannya kembali koperasi makmur sejahtera ini maka perlu di tindak lanjuti dengan pengelolaan manajemen koperasi yang baik, namun demikian masyarakat Kelurahan Titiwungen Selatan Kecamatan Sario Kota Manado yang menjadi pengurus dan anggota koperasi belum memiliki pengetahuan yang lengkap tentang manajemen koperasi .

Untuk itu Pengabdian kepada masyarakat kali ini adalah menindak lanjuti apa yang telah dicapai pada pengabdian masyarakat terdahulu dengan mengusulkan judul Pelatihan manajemen Koperasi Makmur Sejahtera Kelurahan Titiwungen Selatan Kecamatan Sario Kota Manado.

\section{KAJIAN LITERATUR}

\section{Teori Manajemen}

Teori Manajemen berkembang dengan sangat cepat terutama dengan adanya berbagai studi yang dilakukan oleh banyak perguruan tinggi yang kemudian menghadirkan berbagai teori manajemen dari beberapa aliran. Umumnya, beberapa menyebutkan teori-teori manajemen bisa diklompokkan kedalam 6 aliran teori manajemen:

1. Teori Manajemen Aliran Klasik

Teori Manajemen yang memiliki aliran klasik ini menyatakan bahwa manajemen sesuai dengan fungsi fungsi yang terdapat pada manajemen. Teori manajemen klasik tak lepas dari birokrasi yang berdasarkan pada dasar hierarki. Oleh karenanya pada aliran klasik ini terdapat pembagian kerja, struktur organisasi, hierarki proses fungsional serta pengawasan.

Kemampuan dan perhatian manajemen diarahkankepada penerapan fungsi manajemen tersebut. Prinsip Teori Manajemen Aliran Klasik ini pertama kali muncul dikarenakan adanya revolusi industri pada abad 18 yang terjadi di Inggris. Kala itu parah ahli memberi perhatian lebih kepada masalah masalah yang muncul dalam bidang manajemen dikalangan industri, usahawan maupun masyarakat. Teori Manajemen Klasik ini memiliki beberapa kelebihan dan sekaligus beberapa kelemahan. 
2. Teori Manajemen Aliran Perilaku

Teori Manajemen Aliran Perilaku atau yang juga diistilahkan dengan aliran hubungan manusia memusatkan segala kajian kepada aspek manusia serta perlunya memahami karakter manusia. Aliran Perilaku ini mempergunakan disiplin ilmu sosiologi dan psikologi dalam penerapannya.

Teori manajemen aliran perilaku ini menyadari betapa pentingnya hubungan antar personal dalam organisasi. Hawthrone mengemukakan bahwa insentif tidak lebih berpengaruh dari kondisi sosial yang sedang dialami pekerja sama seperti halnya tekanan dari kelompok, atau penerimaan rasa yang aman.

Aliran Perilaku ini muncul dikarenakan pada pendekatan aliran klasik, efisiensi dalam produksi dan keserasian kerja tidak bisa diperoleh. Manajer masih banyak menghadapi berbagai kesulitan karena umumnya pekerja tidak selalu bisa mengikuti pola pola perilaku rasional. Oleh karenanya dilakukan upaya untuk membantu manajer dalam mengatasi masalah yang timbul karena perilaku pekerja

Aliran perilaku menganggap organisasi pada dasarnya adalah orang. teori manajemen aliran klasik dianggap tidak lengkap karena efisiensi produk dan keharmonisan dengan pekerja tidak bisa tercapai. Didalam organisasi, manusia tidak bisa dengan mudah untuk diramalkan tingkah lakunya, Maka teori ini menghubungkan permasalahan tersebut dengan sisi psikologis dan sosiologis.

3. Teori Aliran Manajemen Ilmiah

Pada teori manajemen ini mempergunakan ilmu statistik dan matematika dalam mengembangkan teori teorinya. Aliran manajemen ilmiah menyatakan masalah masalah manajemen bisa dijelaskan dengan pendekatan kuantitatif. Dalam pengelolaan aktivitas manajemen dan kepemimpinan dilakukan dengan mempergunakan dasar dasar yang berpedoman pada teori keilmuan.

Beberapa ciri ciri teori manajemen aliran manajemen ilmiah bisa dilihat sebagai berikut:

$\checkmark$ Mempergunakan prinsip dan cara kerja keilmuan sebagai percobaan dan penyelidikan yang juga ilmiah;

$\checkmark$ Adanya rasionalisasi, maksudnya bekerja sesuai dengan perhitungan maupun pemikiran yang teliti dan juga cermat sehingga bisa tida menggunakan trial and error;

$\checkmark$ Adanya standarisasi, maksudnya bekerja berdasarkan pada ukuran tertentu, baik dalam hal waktu, cara kerja ataupun hasil produksi yang diinginkan;

$\checkmark$ Produktivitas yang meningkat sebagai hasil dari kerja yang efektif dan juga efisien Hasil ataupun cara kerjanya bisa memenuhi tuntutan 
kebutuhan yang semakin meningkat; dan

$\checkmark$ Dalam teori Aliran Manajemen Ilmiah ini juga diusahakan optimasi yang melalui pendekatan ilmiah agar menghasilkan hasil semaksimal mungkin dengan cara yang paling efisien. Didalam aliran ini terdapat koreksi terhadap aktivitas yang tidak efisien, kurang terstrukture atau bahkan tidak dibutuhkan. Aliran ini juga memiliki beberapa kelebihan dan juga kelemahan.

4. Teori Manajemen Aliran Analisis Sistem Aliran Analisis Sistem ini fokus terhadap pemikiran pada permasalahan yang berkaitan dengan bidang lain dialam pengembangan teorinya. Semisal subbagian kepegawaian menyatakan keberhasilan didalam memotivasi pekerja bisa meningkatkan keuntungan organisasi.memotivasi pekerja akan berhubungan dengan kesejahteraan, jam kerja, penggajian, jaminan dihari tua serta faktor lainnya

Analisis Sistem merupakan penguraian atas suatu sistem informasi yang lengkap kedalam bagian bagian komponen yang bermaksud untuk mengidentifikasi serta mengevaluasi masalah, kesempatan, hambatan serta kebutuhan yang nantinya bisa diusulkan adanya perbaikan. Pada teori manajemen ini mengemukakan suatu proses dalam mengumpulkan serta mengintepretasikan kenyataan yang ada, mendiagnosa segala persoalan serta mempergunakan keduanya untuk memperbaiki sistem.

\section{Aliran Manajemen Berdasarkan Hasil}

Aliran ini pertama kali dikenalkan oleh Peter Drucker disekitar tahun 1950an, Aliram manajemen ini fokus pada pemikiran hasil hasil yang diperoleh, bukan kepada interaksi atas aktivitas karyawan. Teori manajemen berdasarkan hasil memiliki tujuan untuk meraih hasil yang optimal berdasarkan pada perjanjian yang terukur dan jelas dibuat dimuka. Manajemen menetapkan prioritas dan tujuan menentukan dan membuat sumber daya yang diperlukan tersedia.

Didalam Aliran berdasarka hasil, terdiri atas langkah langkah seperti berikut:

$$
\begin{aligned}
\checkmark & \text { Penetapan target }- \text { tujuan } \\
& \text { manajemen jangka panjang; } \\
\checkmark & \text { Menerjemahkan tujuan organisasi } \\
& \text { dengan tujuan divisi serta individu; } \\
\checkmark & \text { Hasil perjanjian orientasinya } \\
& \text { mengenai tujuan Implementasi, dan } \\
& \text { pelaporan manajemen; dan } \\
\checkmark & \text { Penilaian periodik, kontrol dan } \\
& \text { penyesuaian. }
\end{aligned}
$$

6. Teori Aliran Manajemen Mutu Teori aliran manajemen mutu fokus terhadap pemikiran atas usaha usaha dalam meraih kepuasan konsumen. Jadi Fokus utama manajemen mutu adalah PELANGGAN sebagai pihak yang bisa menyebutkan apakah produk yang dihasilkan bermutu atau tidak bermutu. 
Manajemen mutu merupakan aspek dari semua fungsi manajemen yang melaksanakan kebijakan mutu dan juga merupakan filsafat budaya organisasi yang lebih menekankan kepada usaha menciptakan mutu yang konsisten melalui tiap tiap aspek didalam kegiatan perusahaan.

Manajemen mutu sangat membutuhkan figur kepemimpinan yang bisa memotivasi karyawan supaya bisa memberikan usaha dan kontribusi yang maksimal kepada organisasi. Hal ini bisa dijalakan dengan memahami dan menjiwai bahwa mutu produk yang dihasilkan bukan hanya tanggung jawab pimpinan semata, melainkan tanggung jawab semua anggota yang ada didalam organisasi. Standard mutu yang diinginkan membutuhkan kesepakatan serta partisipasi penuh dari semua anggota organisasi, sedangkan manajemen mutu tanggung jawabnya terdapat pada puncak pimpinan.

\section{Pelatihan}

Pelatihan adalah suatu proses dimana orang-orang mencapai kemampuan tertentu untuk membantu mencapai tujuan organisasi dan merupakan bagian dari pendidikan yang menyangkut proses belajar untuk memperoleh dan meningkatkan keterampilan diluar system pendidikan yang berlaku dalam waktu yang relative singkat dengan metode yeng lebih mengutamakan pada praktek daripada 48 teori. Dalam penelitian ini motoda pelatihannya adalah motoda on tho job. Oleh karena itu, proses ini terikat dengan berbagai tujuan organisasi, pelatihan dapat dipandang secara sempit maupun luas, secara terbatas, pelatihan menyediakan para karyawan dengan pengtahuan yang sfesifik dan dapat diketahui serta keterampilan yang digunakan dalam pekerjaan mereka saat ini.

Pelatihan merupakan suatu perbaikan kinerja dan meningkatkan motivasi kerja para karyawan yang dibebankan padanya, sehingga karyawan mengalami kemajuan dalam hal pengetahuan, keterampilan dan keahliannya sesuai dengan bidang pekerjaannya.

\section{Maksud Pelatihan}

Alasan utama bagi organisasi untuk melaksanakan pelatihan adalah memastikan organisasi mendapat imbalan yang terbaik dari modal yang ditanam pada sumber yang paling penting (dan sering kali yang paling mahal) pegawainya. Dengan memperhitungkan efek ini, maka tujuan dari setiap pelatihan adalah meraih perubahan dalam pengetahuan, keahlian, pengalaman, tingkah laku, atau sikap yang akan meningkatkan keefektifan pegawai. Menurut Barry Cushway (2002: 116), secara khusus pelatihan akan digunakan untuk:

- Mengembangkan keahlian dan kemampuan individu untuk memperbaiki kinerja; 
- Membiasakan pegawai dengan system, prosedur, dan metode bekerja yang baru; dan

- Membantu pegawai dan pendatang baru menjadi terbiasa dengan persyaratan pekerjaan tertentu dan persyaratan organisasi.

\section{Tujuan Pelatihan}

Menurut Andrew F. Sikula dalam colonel kalsusi lamor taryo (1996:60) tujuan diadakannya pelatihan adalah :

$\checkmark$ Meningkatkan penghayatan jiwa dan idiologi;

$\checkmark$ Meningkatkan produktivitas kerja;

$\checkmark$ Meningkatkan kualitas kerja;

$\checkmark$ Meningkatkan ketetapan perencanaan SDM;

$\checkmark$ Meningkatkan sikap moral dan semangat kerja;

$\checkmark$ Meningkatkan rangsangan karyawan mampu berkinerja secara maksimal;

$\checkmark$ Meningkatkan keselamatan kerja;

$\checkmark$ Meningkatkan keusangan; dan

$\checkmark$ Meningkatkan perkembangan karyawan.

\section{Prinsip-prinsip Pelatihan}

Idealnya, pelatihan akan lebih efektif jika metode pelatihan disesuaikan dengan sikap pembelajaran peserta dan jenis pekerjaan yang dibutuhkan oleh organisasi. Adapun prinsip pembelajaran merupakan suatu guediline (pedoman) dimana proses belajar akan berjalan lebih efektif, semakin banyak prinsip ini direfleksikan dalam pelatihan. Dengan demikian prinsip pembelajaran menurut Veitzhal Rivai (2004:239) adalah sebagai berikut :

$\checkmark$ Partisipasi meningkatkan motivasi dan tanggapan sehingga menguatkan proses pembelajaran. Sebagai hasil partisipasi, peserta akan belajar lebih cepat dan mempertahankan pembelajaran jangka panjang;

$\checkmark$ Pengulangan merupakan proses mencetak satu pola kedalam memori pekerja. Relevansi pembelajaran akan sangat membantu apabila materi yang dipelajari mempunyai arti yang maksimal. Sebagai contoh, instruktur biasanya menjelaskan secara keseluruhan tujuan dari pekerjaan kepada peserta pelatihan sebelum menjelaskan tugas - tugas khusus;

$\checkmark$ Pengalihan (transfer) semakin dekat kesesuaian antara program kebutuhan pelatihan, semakin cepat pekerja dapat belajar dari pekerjaan utama; dan

$\checkmark$ Umpan balik memberikan informasi kepada peserta mengenai progress atau kemajuan yang dicapai, sehingga peserta dapat menyesuaikan sikap untuk mendapatkan hasil sebaik mungkin mereka dapat menjadi tidak puas

\section{Manajemen Koperasi}

Hendrojogi (2007:56) mengatakan bahwa manajemen koperasi melibatkan empat unsur yaitu: Anggota, Pengurus, 
Manajer, Dan Karyawan. Seorang manajer dituntut dapat menciptakan suasana yang dapat mendorong para karyawan agar mempertahankan produktifitas yang tinggi. Karyawan merupakan penghubung antara manajemen dan anggota pelanggan.

Kurnadi (2004:64) mengemukakan bahwa manajemen koperasi pada dasarnya dapat ditelaah dari tiga sudut pandang yaitu organisasi, proses dan gaya. Dari sudut pandang organisasi,manajemen koperasi pada prinsipnya terbentuk dari tiga unsur: Anggota, Pengurus, dan Karyawan. Selain itu dapat dibedakan struktur atau alat perlengkapan organisasi yang sepintas adalah sama yaitu: Rapat Anggota, Pengurus, dan Pengawas. Untuk itu, hendaknya dibedakan antara fungsi organisasi dan fungsi manajemen. Fungsi pengawas seperti yang ada pada alat kelengkapan organisasi koperasi pada hakekatnya adalah merupakan perpan-jangan tangan dari para anggota untuk mendampingi pengurus dalam melakukan fungsi kontrol sehari-hari terhadap jalanya roda organisasi dan usaha koperasi. Berhasil dan tidaknya koperasi salah satunya tergantung pada kerja sama ke tiga unsur organisasi tersebut dalam mengembangkan organisasi dan usaha koperasi yang dapat memberikan pelayanan dengan sebaik-baiknya pelayanan kepada anggotanya.

Dari sudut pandang proses, manajemen koperasi lebih mengutamakan demokrasi dalam mengambil keputusan stragis koperasi. Istilah satu orang satu 50 suara (one man one vote) sudah menjadi harga mati dalam organisasi koperasi. Karena itu, manajemen koperasi sering dipandang kurang efisien, kurang efektif dan sangat mahal. Terakhir ditinjau dari sudut pandang gaya manajemen (managemen style), manajemen koperasi menganut gaya partisipatif (partisipation management), dimana posisi anggota ditempatkan sebagai subyek dan manajemen yang aktif dalam mengendalikan manajemen perusahaanya.

Widiyawati (2002:71) mengemukakan bahwa sistem manajemen di lembaga koperasi harus mengarah kepada manajemen partisipatif yang didalamnya terdapat kebersamaan, keterbukaan sehingga setiap anggota koperasi baik yang turut dalam pengelolaan ataupun diluar kepengurusan (anggota biasa), memiliki rasa tanggung jawab tanggung jawab dalam menyelenggarakan organisasi tersebut.

Tamba (2001:47) mengemukakan badan usaha koperasi di Indonesia memiliki manajemen koperasi yang dianut berdasarkan perangkat organisasi koperasi, yaitu: Rapat Anggota, Pengurus, Pengawas dan Pengelola. Telah diuraikan sebelumnya bahwa watak manajemen koperasi ialah gaya manajemen partisipatif. Pola umum manajemen partisipatif mengambarkan adanya interaksi antar unsur dalam manajemen koperasi, terdapat pembagian tugas (job description), pada masingmasing unsur tersebut. Damikian pula setiap unsur manajemen memiliki lingkup 
keputusan (dicision area) yang berbeda. Meski demikian masi ada lingkup kepusan yang dilakukan secara bersama (shared decision areas).

Tamba (2001:48) menjelaskan bahwa lingkup keputusan masing-masing unsur manajemen koperasi sebagai berikut:

1. Rapat Anggota merupakan pemegang kekuasaan tertinggi dalam menetapkan kebijakan umum dibidang organisasi, manajemen, dan usaha koperasi. Kebijakan yang sifatnya sangat strategis dirumuskan dan ditetapkan pada forum Rapat Anggota. Umumnya, Rapat Anggota diselenggarakan sekali setahun.

2. Pengurus dipilih dan diberhentikan oleh Rapat anggota. Dengan demikian, pengurus dapat dikatakan sebagai pemegang kuasa rapat anggota dalam mengoperasionalkan kebijakankebijakan strategi yang telah ditetapkan Rapat Anggota. Penguruslah yang mewujudkan arah kebujakan kebijakan strategis yang menyangkut organisasi maupun usaha.

3. Pengawas mewakili anggota untuk melakukan pengawasan terhadap pelaksanaan kebijakan yang dilaksanakan oleh pengurus. Pengawas dipilih dan diberhentikan dalam Rapat Anggota. Oleh sebab itu, dalam struktur organisasi koperasi posisi pengawas dan pengurus adalah sama.

4. Pengelola adalah tim manajemen yang diangkat dan diberhentikan oleh pengurus untuk melaksanakan teknis operasional bidang usaha. Hubungan pengelola usaha (managing director) dengan pengurus koperasi adalah hubungan kerja atas dasar perikatan dalam bentuk perjanjian atau kontrak kerja.

\section{METODE PENGABDIAN}

Metode Pelajaran di kelas (ceramah, konfrensi, studi kasus, permainan,program instruksi, brainstroming). Kegiatan yang akan dilakukan dalm upaya mengembangkan program pelatihan yang efektif, yaitu :
a. Perencanaan,
b. Implementasi/Pelaksanaan..
c. Evaluasi program pelatihan.

\section{HASIL DAN PEMBAHASAN}

\section{Perencanaan Analisa Kebutuhan \\ Pelatihan Organisasi}

Mitra dalam kegiatan ini adalah Pengurus dan Anggota Koperasi Makmur Sejahtera Kelurahan Titiwungen Selatan kecamatan Sario Kota Manado yang berdasarkan analisis situasi dapat diperoleh permasalahan prioritas yang dihadapi yaitu: 1. Bagaimana agar tujuan koperasi Makmur Sejahtera tercapai?;

2. Bagaimana agar manajemen koperasi Makmur Sejahtera berjalan dengan baik?;

3. Kurangnya kesadaran dan peran serta masyarakat untuk aktif dalam kegiatan perkoperasian; dan 
4. Tidak adanya pengawasan yang berkelanjutan dalam mengawasi jalannya koperasi agar tujuan dapat tercapai.

\section{Sasaran dan Materi Program}

Kelompok sasaran dalam Pengabdian pada masyarakat ini yaitu Pengurus dan anggota koperasi makmur sejahtera yang berada di Kelurahan Titiwungen Selatan Kecamatan Sario Kota Manado yang berjumlah 15 orang.

Pelaksanaan pelatihan ini dilakukan selama 1 hari dengan melibatkan instansi yang terkait yaitu Dinas koperasi Kota Manado yang berkontribusi bersama dengan pelaksana pengabdian ini dalam memberi materi manajemen koperasi.

Materi dalam pelatihan ini yaitu tentang Manajemen Koperasi dimana Koperasi lazimnya seperti organisasi yang lain membutuhkan manajemen yang baik agar tujuan yang telah digariskan koprasi tersebut dapat tercapai sesuai denga harapan. Hal yang membedakan manajemen koperasi dengan manajemen umum terletak pada unsur-unsur manajemen koperasi yaitu rapat anggota, pengurus dan pengawas. Adapun tugas masing-masing dapat diperinci sebagai berikut: Rapat Anggota bertugas untuk menetapkan anggaran dasar, membuat kebijakan umum, mengangkat dan memberhentikan pengurus dan pengawas.

Pengurus koperasi bertugas memimpin koperasi dan usaha koperasi 52 sedangkan pengawas tugasnya mengawasi jalanya koperasi, unuk koperasi yang usahanya banyak dan luas pengurus dimungkinkan mengangkat manajer dan karyawan. Manajer dan keryawan tidak harus anggota koperasi dan seyogyanya memang diambil dari luar koperasi sehingga pengawasanya lebi mudah mereka berkerja karena ditugasi oleh pengurus, maka mereka juga bertanggung jawab kepada pengurus. Dalam manajemen koperasi maka tidak terlepas dari perencanaan, pembagian kerja, pengarahan, dan pengawasan. Lebih jelasnya diuraikan sebagai berikut:

1. Perencanaan

Perencanaan merupakan proses dasar manajemen dalam perencanaan manajer memutuskan apa yang harus dilakukan, kapan harus dalakukan, bagaimana melakukan, dan siapa ynag harus melakukan. Setiap organisasi memerlukan perencanaan, baik organisasi yang bersifat kecil maupun besar sama saja membutuhkan perencanaan namun dalam pelaksanaanya memerlukan penyesuaian-penyesuaian dengan melihat bentuk tujuan dan luas organisasi yang bersangkutan.

Perencanaan yang baik adalah perencanaan yang fleksibel, sebab perencanaan akan berbeda dalam situasi yang terus barubah dari waktukewaktu. Apabila perlu dalam pelaksanaanya diadakan perencanaan 
kembali sehingga semakin cepat tercapainya tujuan koperasi tersebut. Ada empat tahap dasar perencanaan, yaitu: (1) menetapkan tujuan dan serangkaian tujuan, (2) merumuskan keadaan saat ini, (3) mengidentifikasi segala kemudahan dan hambatan, (4) mengembangkan rencana atau serangkaian kegiatan untuk pencapaian tujuan. Perencanaan yang dibuat oleh perusahaan yang satu dengan perusahaan lainya belum tentu sama perbedaan tersubut terjadi karena tipe organisasi yang berbeda, jangka waktu yang digunakan, tipe manajer yang yang mengelola perusahaan.

Secara garis besar ada dua tipe tipe perencanaan strategis mencakup proses pemilihan tujuan organisasi, penentuan strategis, kebijaksanaan dan program untuk menjamin bahwa tujaun organisasi dapat dicapai. Sedangkan redangkan rencana operasional menguraikan lebih rinci bagaimana rencanarencana strategis akan dicapai.

Perencanaan daalam koperasi sama dengan organisasi lainya perlu dikelola dengan baik agar dapat dicapai tujuan akhir seefektif mungkin fungsi perencanaan merupakan fungsi manajemen yang sangat penting karena merupakan dasar dari fungsi manajemen yang lain. Agar tujuan akhir koperasi dapat dicapai maka koperasi harus membuat rencana yang baik dengan melalui beberapa langkah dasar pembuata rencana yaitu menentukan tujuan organisasi mengajukan alternatif cara mencapai tujuan tersebut dan kemudian alternatif-alternatif tersebut harus dikaji satu persatu sebelum diputuskan alternatif mana yang sangat baik mendukung untuk mencapai tujuan tersebut. Tipe rencana yang dapat diambil dalam koperasi dapa bermacam-macam tergantung pada jangka den kebutuhan organisasi koperasi.

2. Pembagian kerja

Pengorganisasian merupakan suatu proses untuk merancang struktur formal, mengelompokan, mengatur dan membagi tugas masing-masing unsurunsur yang ada agar tujuan organisasi dapat dicapai secara efisien. Pelaksanaan proses pengorganisasian akan menggambarkan struktur organisasi yang menunjukan aspek-aspek penting seperti: pembagian kerja, departementalisasi, bagan organisasi, rantai perintah dan kesatuan perintah, tingkat hirarki manajemen, saluran komunikasi dan sebagainya.

Sebagai pengelola koperasi pengurus senantiasa berhadapan dengan beragam masalah yang mesti diselesaikan dengan sesegerah mungkin, salah satu masalah yang paling sulit adalah masalah yang timbul dari internal koperasi tersebut yaitu keterbatasan. Ketarbatasan yang dimaksud dalah pengetahuan sebab seorang pengurus harus diangkat oleh dari anggota sehingga tidak menjamin 
dia merupakan anggota yang cukup profesional di bidan pengelolaan koperasi tersebut. Dengan kemampuan yang terbatas ditambah tingkat pendidikan yang terbatas pengurus perlu mengangkat keryawan yang bertugas membantunya dalam mengelola koperasi agar pekerjaan koperasi dapat dilaksanakan sesuai dengan yang diharapkan.

Masuknya berbagai pihak yang ikut membantu pengurus mengelola usaha koperasi semakin kompleks pula struktur organisasi tersebut. Pemilihan bentuk struktur koperasi harus disesuaikan dengan jenis usaha, volume usaha, maupun luas pasar dan produk yang dihasilkan

\section{Pengarahan}

Pengarahan merupakan fungsi manajemen yang sangat penting sebab setiap anggota yang berkerja didalam suatu organisasi mempunyai kepentingan yang berbeda-beda. Agar kepentingan tersebut tidak berbenturan maka pemimpin harus berperan mengarahkan agar dapat mencapai tujuan arganisasi.

Seorang karyawan dapat menunjukan prestasi kerja yang baik apabila memperoleh motivasi disinilah tugas pemimpin untuk memberikan motivasi kepada keryawanya agar mereka menggunakan potensi yang dimilikinya untuk mencapai tujuan yang hendak dicapai. sepaya manajer atau pimpinan perusahaan dapat memberikan pengarahaan yang baik pertama-tama yang harus diperhatikan pimpinan harus mempunyai kemampuan untuk memimpin perusahaan dan pandai mengadakan komunikasi vertikal.

4. Pengawasan

Pengawasan adalah suatu usaha sistematik untuk membuat semua kegiatan perusahaan sesuai dengan rencana. Proses pengawasan dapat dilakukan dengan melalui beberapa tahap, yaitu menetapkan standar, membandingkan kegiatan yang dilaksanakan dengan standar yang sudah ditetapkan, mengukur penyimpangan-penyimpangan yang terjadi, dan yang terjadi mengambil tindakan koreksi apabila diperlukan. Setiap perusahaan-perusahaan melakukan pengawasan dengan tujuan agar pelaksanaan kegiatan sesuai dengan rencana yang telah ditetapkan.

Ada beberapa alasan mengapa perusahaan menghendaki adanya pengawasan yang baik. Alsan-alasan tersebut antara lain:

a. Manajer dapat lebih cepat mengantisipasi perubahan lingkungan;

b. Perusahaan yang lebih besar akan lebih muda dikembalikan; dan

c. Kesalahan-kesalahan yang dilakukan oleh anggota organisasi dapat dikurangi.

Berdasarkan waktu melakukan pengawsan dikenal tiga tipe pengawasan yaitu, feedforward controll, concurent control, dan feedback control. 
Secara garis besar pengawasan dapa dibagi menjadi dua yaitu metode pengawasan kualitatif dan metode pengawasan kuantitatif. Metode pengawasan kualitatif dilakukan oleh manajer untuk menjaga feformance organisasi secara keseluruhan, sikap dan peformance karyawan. Metode pengawasan kuantitatif dilakukan dengan menggunakan data biasanya digunakan untuk mengawasi kuantitas dan kualits produk, ada beberapacara yang yang biasa digunakan untuk melakukan pengawasan kuantitatif, antara lain: dengan menggunakan anggaran, mengadakan auditing, analisis break even, analisi rasio, dan sebagainya.

\section{Metode pelatihan dan prinsip-prinsip}

\section{belajar yang digunakan}

Metode Pelajaran di kelas dengan prinsip belajar yang digunakan yaitu ceramah, konfrensi (diskusi), studi kasus, permainan, program instruksi, brainstroming.

\section{Implementasi/Pelaksanaan}

Dalam implementasi pelatihan ada berapa tahap yang telah dilakukan yaitu, tahap awal mencangkup pengumpulan peserta, penyediaan fasilitas dan logistik, orientasi dan tes awal (persepsi peserta terhadap pelatihan). Tahap selanjutnya penyampaian materi pelatihan dan tahap terakhir merupakan pelaksanaan post test terhadap hasil pelatihan
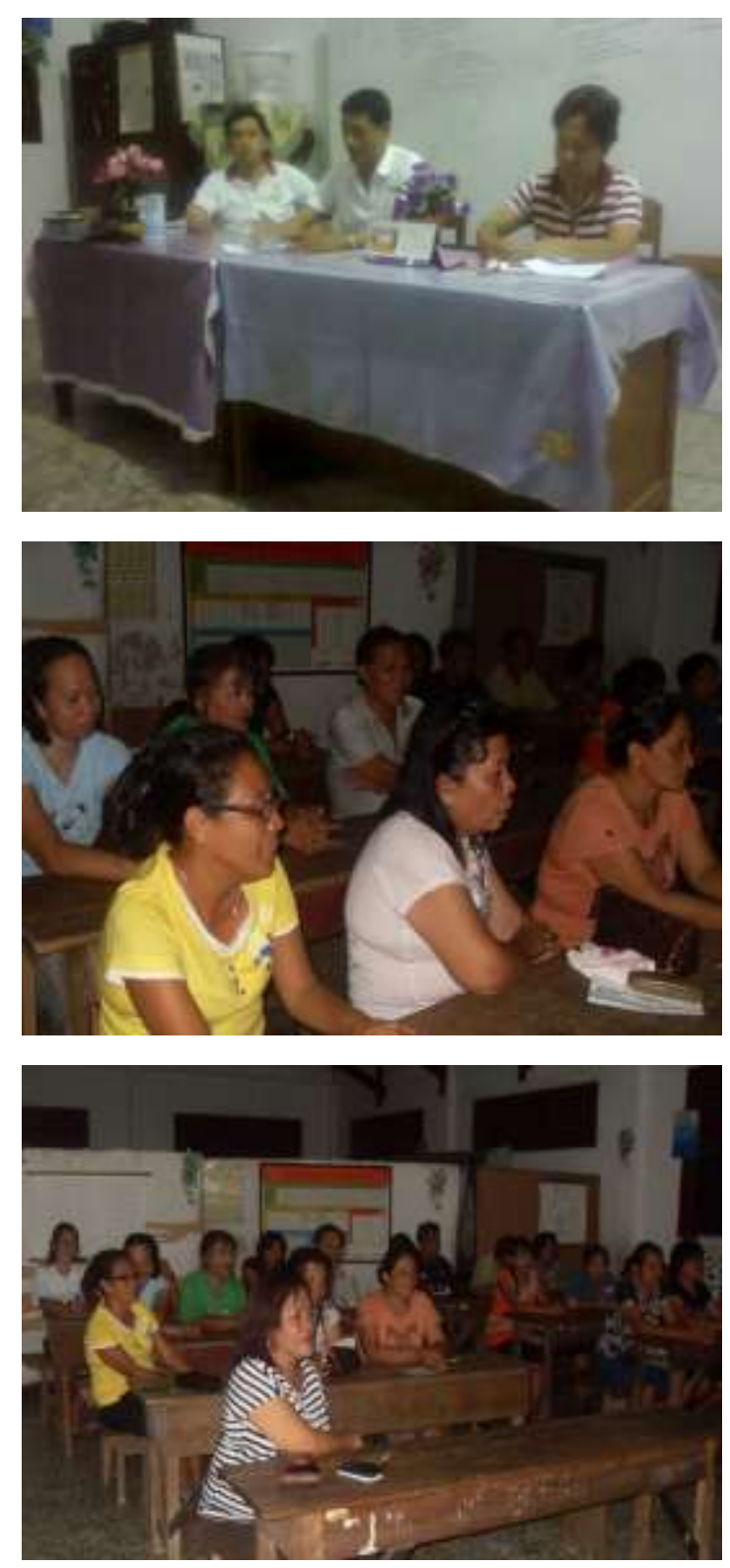

Gambar 1. Dokumentasi Pelaksanaan Pelatihan

\section{Evaluasi Program Pelatihan}

Tujuan dilaksanakannya evaluasi yaitu Untuk mendapatkan masukan, kritik dan saran guna melihat tingkat keberhasilan pelaksanaan kegiatan pelatihan. Evaluasi dilaksanakan Setiap akhir session (untuk evaluasi per session),Setiap hari (untuk evaluasi harian) 
dan Pada akhir kegiatan (untuk evaluasi kegiatan secara keseluruhan)

\section{KESIMPULAN DAN SARAN}

\section{Kesimpulan}

- Anggota dan pengurus koperasi sangat tertarik dan gembira dengan diadakannya pelatihan manajemen koperasi.

- Anggota koperasi dan pengurus telah mendapat pengetahuan tentang majemen koperasi yang baik.

- Anggota dan pengurus koperasi termotivasi menerapkan pola manajemen koperasi yang sudah mendapat pelatihan.

\section{Saran}

- Kegiatan Pengabdian ini dapat dilanjutkan dalam bentuk kegiatan yang lain seperti Pelatihan Pengawasan dalam pengelolaan Koperasi.

- Perlunya kerja sama antar koperasi untuk memberikan pelatihan tentang manajemen koperasi.

\section{KEPUSTAKAAN}

Achmad,Merencanakan Latihan dan Pengembangan,Pusat latihan dan penataran

perkoperasian Direktrat Jendral bina lembaga koperasi, Jakarta, 1992.

Basir Barthos,Manajemen Sumber Daya Manusia Suatu Pendekatan Makro,Jakarta : Bumi Aksara, 1993.

Haris Mujiman,Manajemen Pelatihan Berbasis Belajar Mandiri,Pustaka Pelajar,2007.

Harold Koontz dkk,Intisari Manajemen,Jakarta : PT. Bina Aksara, 1989.

Malayu S.P. Hasibuan,Manajemen (Dasar, Pengertian dan masalah),JakartaPT. Bumi Aksara, 2006.

Marihot Tua Efendi H.,Manajemen Sumber Daya Manusia,Jakarta :PT.Grasindo, 2005.

Ninik Widianti,Manajemen Koperasi, Jakarta : PT. Rineka Cipta, 1994.

Oemar Hamalik,Pengembangan Sumber Daya Manusia, Manajemen Pelatihan Ketenagakerjaan Pendekatan Terpadu Jakarta : PT. Bumi Aksara, 2001.

Undang-undang RI nomor 25 Tahun 1992 TentangPerkoperasian 